\title{
Thusa Phase II: The design of a nutrition intervention education programme
}

\author{
Lesley A Greyvenstein, Susanna M Hanekom, \\ H Salomé Kruger \& Gerda M Reitsma
}

\begin{abstract}
OPSOMMING
Hierdie artikel bespreek die multidissiplinêre en multimetodologiese navorsingsproses wat vir die ontwikkeling van ' $n$ voedingsintervensie-opvoedingsprogram gebruik is. Die navorsing het tien stappe behels, insluitende kwalitatiewe en kwantitatiewe metodologie. 'n Literatuurstudie en ' $n$ gemeenskapsprofielstudie is uitgevoer, vraelyste is bestudeer, en fokusgroepbesprekings, waarneming en konsultasie is gedoen. Die voedingsintervensie-opvoedingsprogram berus op die data wat ingesamel is. Agt eenvoudige voedingsboodskappe is geformuleer om die probleme van mikronutriëntondervoeding asook -oorvoeding wat met vetsug geassosieer word in 'n lae-inkomstepopulasie aan te spreek. Implementerings- en evalueringsriglyne is beplan om ' $n$ betekenisvolle verskil in die eetpatrone van die Tswana-bevolking in die Noordwes-Provinsie te maak.
\end{abstract}

\section{- LA Greyvenstein}

School of Physiology, Nutrition \& Family Ecology, Potchefstroom University for CHE

\section{- SM Hanekom}

School of Physiology, Nutrition \& Family Ecology, Potchefstroom University for CHE

\section{- HS Kruger}

School of Physiology, Nutrition \& Family Ecology, Potchefstroom University for CHE

\section{ORIENTATION AND PROBLEM STATEMENT}

During urbanisation and the acculturation of developing countries in the world, the ideal move to optimum nutrition is seldom achieved and there is usually a move from undernutrition to overnutrition. this is often accompanied by a shift from diseases of undernutrition such as pellagra, kwashiorkor and increased infections to diseases of overnutrition such as diabetes, hypertension, strokes and eventually coronary heart disease and colon cancer. Macronutrient overnutrition and micronutrient undernutrition are found in the same household, or even the same person. These lifestyle diseases are expensive to treat and place a heavy burden on a country's health budget. It is evident that both overnutrition and undernutrition can be prevented by following an adequate but prudent diet plus a healthy lifestyle (Vorster et al, 1997:4).

South Africa is a developing or Third World country. However, it is unique because of the technologically developed component of the population who may be classified as living according to First World standards. Current socioeconomic and political factors are causing rapid urbanisation and a transition of Third World communities away from a traditional, ethnic lifestyle in rural areas to elements of a First World lifestyle in or close to cities and towns. This transition affects eating patterns and is known to have a detrimental effect on nutrient intake, nutrition status and health, with a consequent negative effect on the quality of life (Popkin \& Doak, 1998:106).

Patel and Pettifor (1992:23) state that human lifestyles and nutrition behaviour should be changed through national education programmes to ensure long-term sustainable improvement. Nutrition education is considered a powerful, dynamic process in improving health (American Dietetic Association, 1990:110). It is recognised, however, that nutritionrelated behaviour is more difficult to change than many other health-related behaviours (Achterberg, 1992:29). Kumanyika (1996:739) maintains that the degree to which low-income groups - usually the main target group - adopt healthy diets is below average.

Nutrition intervention education programmes (NIEP) have been implemented in South Africa with varying degrees of success (McLachlan, 1994:2; Steyn et al, 1992:103; Walker, 1989:44). Intervention programmes sometimes fail because a disproportionate amount of resources and effort go into the planning instead of 
into the actual intervention (Steckler et al, 1992), or the intervention is not appropriate to the specific community (Cliff \& Freimuth, 1995:70; Steckler et al, 1995:321), or the evaluation of the programme has important methodological limitations (Steckler et al, $1995: 309 ; 315)$. It is therefore necessary to identify appropriate methods and instruments for the design, implementation and evaluation of intervention programmes.

According to Achterberg (1992:29), programme success depends on a comprehensive and systematic approach to the conceptualisation, implementation and evaluation of a NIEP. In this context Kok (1992:5) stresses the importance of planning an intervention that addresses the relevant behavioural objectives, of adequate pretesting, individualisation, feedback, reinforcement, support and facilitation. Steyn (1990:36) maintains that formative and summative evaluation forms an essential part of the design, implementation and outcome of an intervention programme.

The programme that is discussed in this article arose from the need for a NIEP identified by the Transition and health during urbanisation of South Africans (THUSA) PHASE I research. The health and nutritional status of the adult black population in the NorthWest Province were determined during this research.

The research covered a range of strata from the totally undeveloped, deep rural areas where a traditional lifestyle is followed, to highly sophisticated urban towns and cities. The data collected during this research showed a tendency towards the increased prevalence of chronic lifestyle diseases such as obesity, hypertension and diabetes mellitus which are associated with excessive energy intake (Vorster, 1997).
However, inadequate micronutrient intake was also established in a large proportion of the subjects (Maclntyre, 1998), indicating a need for a NIEP for the adult Tswana population in the North-West Province. The design of this programme therefore represents PHASE II of the THUSA research.

\section{AIM OF THE RESEARCH}

The main aim of this research was to design a NIEP for the adult Tswana population of the North-West Province of South Africa to improve its general health status via better nutrition.

\section{OUTLINE OF PROCEDURES AND METHODS}

The multidisciplinary research team included expertise in dietetics, home economics, food science, sociology, community development, extension work and education, since these aspects are important in understanding the factors that influence the nutritional status of a community The conceptual framework (Figure 1) of the research is based on the CDC Framework for Health Communication (Donovan, 1995:216).

The multifaceted nature of the situation analysis determined the use of a wide variety of qualitative and quantitative research techniques. These techniques included literature surveys, exploratory visits, a profile study, focus-group methodology, structured interviews, prioritisation sessions and the analysis, interpretation and synthesis of available data (see Table 1).

TABLE 1: RESEARCH STEPS AND TECHNIQUES USED IN THE DEVELOPMENT OF THE NIEP

\begin{tabular}{|c|l|l|}
\hline \multicolumn{1}{|c|}{ Research } & \multicolumn{1}{|c|}{ Research technique } \\
\hline 1. & Nutrition status and nutrition programmes & Literature surveys and reports \\
\hline 2. & Analysis of THUSA PHASE I results & Analysis and interpretation of statistical data \\
\hline 3. & $\begin{array}{l}\text { Introductory exploration of control and experimen- } \\
\text { tal groups }\end{array}$ & Exploratory and observational on-site visits \\
\hline 4. & Compilation of community profile & Questionnaires, information tables, profile study \\
\hline 5. & $\begin{array}{l}\text { Nutrition and health knowledge and practice in the } \\
\text { community }\end{array}$ & Focus-group methodology \\
\hline 6. & Food availability via shopkeepers & Information tables of food items in shops \\
\hline 7. & Food security status & Structured questionnaires and interviews \\
\hline 8. & Dietary intake & Structured questionnaires and interviews \\
\hline 9. & Prioritisation of nutrition education needs & P-index prioritisation and focus-group methodology \\
\hline 10. & $\begin{array}{l}\text { Design of Nutrition Intervention Education Pro- } \\
\text { gramme }\end{array}$ & $\begin{array}{l}\text { Analysis, interpretation and synthesis of available } \\
\text { data }\end{array}$ \\
\hline
\end{tabular}




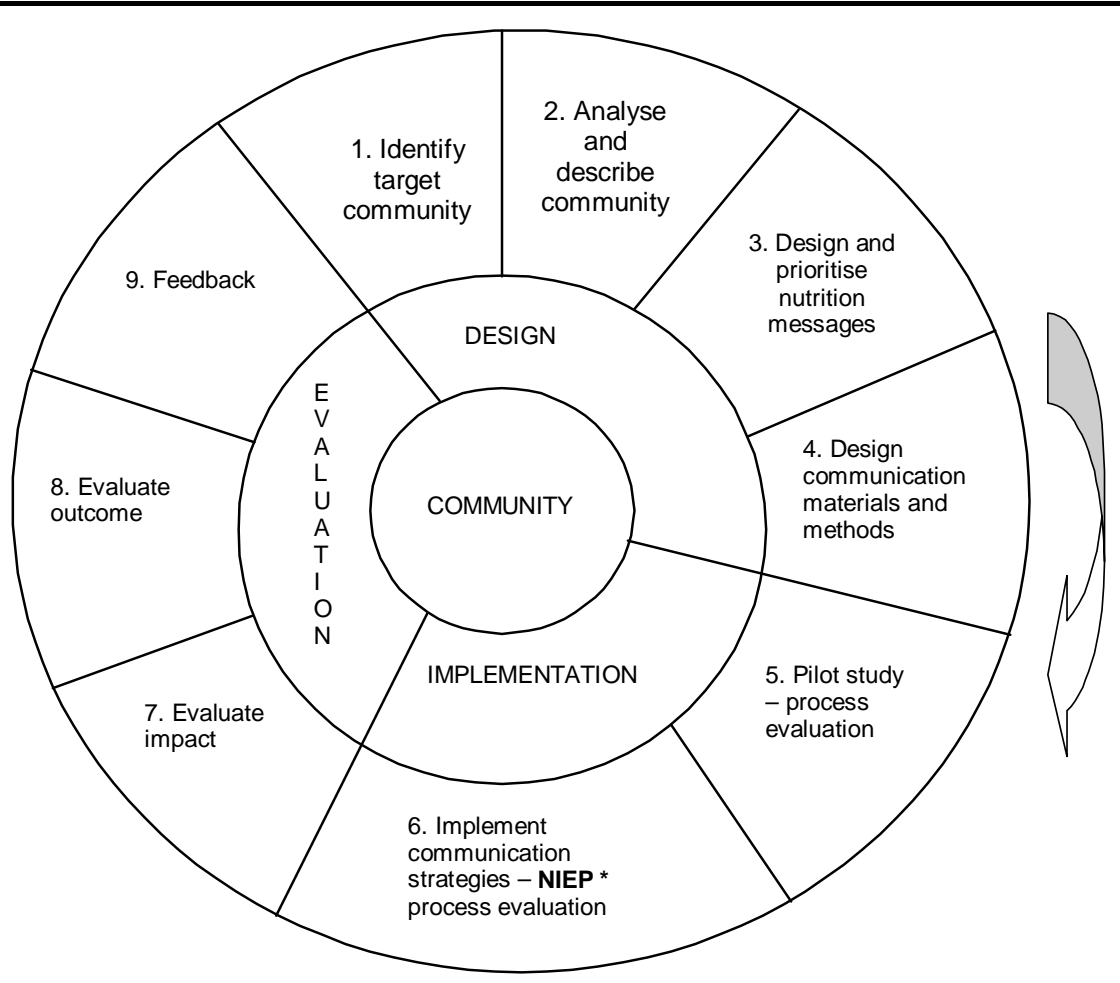

* NIEP: Nutrition Intervention Education Programme

FIGURE 1: CONCEPTUAL FRAMEWORK FOR THE DEVELOPMENT, IMPLEMTATION AND EVALUA-

TION OF A NIEP (Based on CDC framework for health communication, Donovan, 1995:216

\section{Steps in the development process}

1 The status quo with respect to the nutritional status and relevant nutrition programmes in South Africa was determined via a comprehensive literature survey to ascertain prevalent nutrition problems and to establish whether these problems were relieved by existing programmes.

2 The THUSA PHASE 1 baseline study results were used to compile a report on the health and nutrition status of the target population.

3 After consulting the 1996 Business, Population and Central Place Indices of the North-West Province and the Provincial Department of Health and Developmental Welfare, it was decided to target the communities at Tshing near Ventersdorp in the Klerksdorp district and Ipelegeng near SchweizerReneke in the Huhudi region. Financial, time and feasibility constraints were taken into account. Tshing was randomly chosen as the experimental group and Ipelegeng as the control group. Since many factors influence the dietary practices of a community, the impact of a NIEP can only be evaluated if the outcomes are compared with the results in a similar control group.

The target groups were visited in order to build confidence and trust between the researchers and the groups and to gain information which could contribute to the design of an acceptable and successful NIEP.
4 Comprehensive community profiles of the target populations were compiled to reflect information that was relevant to the design of the intervention programme.

5 In-depth data were collected about the eating patterns and health of the target populations.

6 Foods in the local shops were comprehensively surveyed to ascertain which foods were available to the target communities. This survey also provided information on consumer demand for specific products.

7 Food security and hunger patterns in the target populations were determined to determine to what extent the population could afford an adequate food intake.

8 The dietary intakes of the target populations were determined for a comparison with the recommended intake and to identify insufficient nutrients in the target groups' diets.

9 The P-index was used to determine the priorities of nutrition education of the intervention group (Tshing). Points relevant to nutrition were discussed and the participants were allowed to prioritise these topics.

10 A NIEP was designed with reference to the above steps to address the nutrition needs of the population.

A comprehensive multimethodological situation analysis was conducted of all the factors that affect the nu- 
TABLE 2: DEMOGRAPHIC DATA OF THE SUBJECTS COLLECTED DURING THE TSHING COMMUNITY PROFILE STUDY $(\mathrm{N}=149)$

\begin{tabular}{|c|c|c|}
\hline Demographic variable & $\mathbf{N}$ & $\%$ \\
\hline \multicolumn{3}{|l|}{ Age distribution (years) } \\
\hline $16-35$ & 62 & 41,6 \\
\hline $36-55$ & 51 & 34,2 \\
\hline $56-75$ & 26 & 17,4 \\
\hline $76-95$ & 10 & 6,7 \\
\hline \multicolumn{3}{|l|}{ Home language } \\
\hline Afrikaans & 3 & 2 \\
\hline Tswana & 127 & 85,2 \\
\hline Xhosa & 14 & 9,4 \\
\hline Other: Zulu, Shangaan & 5 & 3,4 \\
\hline \multicolumn{3}{|l|}{ Educational status } \\
\hline No school education & 52 & 34,9 \\
\hline Grade 1 -Standard 5 (Grades 1 - 7) & 47 & 31,5 \\
\hline Standard $6-9($ Grades $8-11)$ & 38 & 25,6 \\
\hline Standard 10 (Grade 12) & 10 & 6,7 \\
\hline Tertiary education & 2 & 1,3 \\
\hline \multicolumn{3}{|l|}{ Years of school education* } \\
\hline $0-2$ & 54 & 42,9 \\
\hline $3-5$ & 15 & 11,9 \\
\hline $6-11$ & 44 & 34,9 \\
\hline $12-17$ & 13 & 10,3 \\
\hline \multicolumn{3}{|l|}{ Household income (R/month) ${ }^{\star}$} \\
\hline $0-499$ & 92 & 65,3 \\
\hline $500-999$ & 32 & 22,8 \\
\hline $1000-1999$ & 11 & 7,7 \\
\hline $2000-4999$ & 7 & 4,2 \\
\hline \multicolumn{3}{|l|}{ Number of own children* } \\
\hline $0-2$ & 51 & 37,8 \\
\hline $3-5$ & 51 & 37,8 \\
\hline $6-8$ & 25 & 18,5 \\
\hline $9-12$ & 8 & 5,9 \\
\hline \multicolumn{3}{|l|}{ Number of people in the household ${ }^{*}$} \\
\hline $0-4$ & 9 & 40,7 \\
\hline $5-9$ & 64 & 44,1 \\
\hline $10-14$ & 22 & 15,2 \\
\hline \multicolumn{3}{|l|}{ Number of rooms per house } \\
\hline $1-3$ & 56 & 38 \\
\hline $4-6$ & 84 & 56 \\
\hline $7-12$ & 9 & 6 \\
\hline \multicolumn{3}{|l|}{ Employment status } \\
\hline Unemployed/pensioner & 128 & 85,9 \\
\hline Part-time job & 7 & 4,7 \\
\hline Full-time job & 5 & 3,4 \\
\hline Self-employed (e.g. selling vegetables, shopkeeper) & 9 & 6 \\
\hline
\end{tabular}

* A complete data set was not available for all subjects 
trition status of the population. The design of the NIEP was based on the findings of this situation analysis. The idea was therefore to design a relevant and meaningful intervention programme, based on the current situation of the population.

\section{DETAILED METHODOLOGY FOR AND DISCUS- SION OF EACH STEP}

\section{Step 1}

The first step in the research programme was a comprehensive literature survey of the nutrition status and nutrition programmes in South Africa. All South African medical, nutrition, consumer science and development journals were scanned for reports on the nutrition of South Africans and on nutrition programmes. The review by Vorster et al (1997) on the nutritional status of South Africans and the Report of the Nutrition Committee to the Minister of Health (1994) on nutrition programmes were studied in detail. The diversity in terms of the nutritional status of South Africans includes overnutrition as well as undernutrition (Vorster et al, 1997:32) and this was recognised as a complicating factor in designing a relevant and meaningful NIEP.

According to the Policy Statement on Nutrition Education of the American Dietetic Association (1995:980), nutrition education may be defined as the process by which nutrition information and beliefs, attitudes and environmental influences lead to practices that are scientifically sound, practical and consistent with individual needs and the available food sources.

Nutrition education in South Africa has been addressed by both government and nongovernment organisations via a multitude of programmes. The poor nutrition status, particularly among South African children, prompted the National Department of Health to implement various national nutrition intervention programmes (Vorster et al, 1997:1). However, these programmes, namely the National Nutrition and Social Development Programme (NNSDP) (McLachlan, 1994:1), the Protein Energy Malnutrition Scheme (PEM) and the Primary School Nutrition Programme (PSNP), focused on undernutrition among children (Report of the Nutrition Committee, 1994:8). Vorster et al (1997:1) state that these programmes were neither scientifically nor satisfactorily evaluated and that there was a perception that they were not costeffective. McLachlan and Marshall (1995) described the reasons for their failure as follows:

- The programmes were designed without sufficient information.

- Understanding of the problems of malnutrition was limited.

- The goals were ill-defined.

- Activities were unfocused.

- The emphasis on delivery of specific services such as food handouts was incorrect.

- The programmes did not target the most needy.
- The participation and involvement of the communities were inadequate.

The researchers came to the following general conclusions about nutrition programmes in South Africa and these conclusions affected the aims of this research:

- Good nutrition, defined as an adequate intake of energy and nutrients, should be considered a basic human right since it is a prerequisite for realising the full intellectual and physical potential of people (Report of the Nutrition Committee, 1994: ix).

- The government has identified nutrition education as a priority and supports initiatives that are based on the broad outlines specified in the new National Integrated Nutrition Programme (Report of the Nutrition Committee, 1994:7).

- Nutrition education programmes should form part of the general development initiatives and should be multifaceted (Report of the Nutrition Committee, 1994:7; Lerer \& Yach, 1998:4).

- A participatory approach should incorporate all stakeholders (Report of the Nutrition Committee, 1994:17; McLachlan \& Marshall, 1995).

- Each programme should target specific needs of specific communities and should focus on the most needy (McLachlan, 1994:1; Report of the Nutrition Committee, 1994:18).

- Programmes should address priority issues such as breast-feeding and early childhood feeding, the causes of malnutrition, prevention of both under and overnutrition, food security, micronutrient intake, and the caring capacity of women (Report of the Nutrition Committee, 1994:27).

- Poverty is considered a major cause of malnutrition (Ladzani et al, 1992:60; Report of the Nutrition Committee, 1994:13).

- Sustainability and active participation of the target group are important considerations (Patel \& Pettifor, 1992:23; Report of the Nutrition Committee, 1994:93)

\section{Step 2}

Step 2 of the research studied the baseline data from the THUSA I research. The THUSA I study measured the dietary intake, serum lipid profile, anthropometry and blood pressure of adult volunteers recruited in randomly selected districts of the province (Vorster, 1997).

Although only limited data were available at that stage, the increased prevalence of obesity, moderate hyperlipidaemia and hypertension was evident, particularly in urban subjects in the higher-income group. Their diet in terms of mineral and vitamin intake was of a better quality, but their fat intake was also higher. The people who lived in informal settlements were were characterised by a generally low intake of fibre and micronutrients (Maclntyre, 1998). 


\section{Step 3}

Step 3 comprised introductory visits to the target populations for observation purposes. General living conditions, housing, roads, water and electricity supply and the environment were observed. The clinic sisters and Reconstruction and Development Programme (RDP) officers accompanied the researchers. The local municipality and the clinics were visited to identify key persons who could provide information for the community profile study, for example the number of residents in the target townships, health services and municipal services to the community. The research team got the impression that the experimental and control groups were highly comparable as both were located in semirural areas close to their respective towns. The general quality of life showed considerable poverty but also a willingness to cooperate and to improve the situation.

\section{Step 4}

The community profiles, including the demographics and health statistics of the target populations, were completed during the fourth step in the research process. Nutrition education programmes often focus on the immediate causes of malnutrition only, for example insufficient and unbalanced intake of food. In this regard, Ladzani et al (1992:60) report that nutritionists should be more aware of the socioeconomic factors that compound the problem. Lilley and Johnson $(1996: 23)$ state that general socioeconomic background information should form the basis of any intervention programme aimed at dietary change. There is also a definite relationship between socioeconomic factors such as status, income, occupation, living conditions and nutritional status (Steckler et al, 1995:315; Pincus \& Callahan, 1994:355).

McLachlan and Van Twisk (1995:1) are of the opinion that when community nutrition programmes are based on a holistic understanding of the problem, improvements in the nutritional wellbeing of communities are sustainable. Therefore, in order to gain a holistic understanding of the nutrition problems of the target community, it was imperative to compile an extensive community profile. A sample of 149 households were randomly selected in each target population. Maps of the target townships were used and every eleventh house number was marked by means of a simple, random sampling method (Rimm et al, 1980:23). The same person was interviewed for the demographic, food security (seventh step) and dietary questionnaire (eighth step). The demographic data collected included gender, age, home language, academic qualifications, years of education, monthly income, marital status, number of marriages, length of marriage, number of own and adopted children of a senior member of the household, and number of people in the household. Only the data collected for the Tshing community will be presented here.

In a community profile, the socioeconomic indicators of importance in nutrition-related issues include the major health determinants such as housing, water, sanitation and electricity or alternate energy provision (Lerer \& Yach, 1995:3). Information on household access to food, adequacy of health care services and the general status of the environment should also be considered. These variables were included in the structured questionnaire which was used to collect information from the same randomly selected sample of subjects in the target populations.

Cliff and Freimuth (1995:70) state that a total health problem analysis should be carried out prior to the design of an intervention programme. The demographic data that were gathered by quantitative research techniques were supplemented and confirmed by the information gained during the exploratory visits (step three) and the focus-group discussions that followed (step five) to ascertain the status quo of the community. The design of the NIEP should therefore be based on multifaceted variables which directly or indirectly affect the community. Table 2 presents the demographic data that were collected for the Tshing community profile.

The overall infrastructure of the target population varies from well-cared for brick houses with both electricity and running water to informal shacks with neither electricity nor running water. More than $70 \%$ of the community live in these informal shacks in underdeveloped or semideveloped areas, with access to some running water and pit toilets. Sound sanitation and hygiene facilities were an evident problem in the target communities. The data on infrastructure collected during the community profile study are presented in Table 3. Another major problem in these communities is the high rate of unemployment and therefore lack of income (Table 2).

It is evident that the following community profile factors (Tables 2 and 3 ) should be considered when a NIEP is designed for the population of Tshing:

- The programme should be written in Tswana, with Afrikaans and English notes to facilitate training.

- The economical use of available energy sources should be considered, particularly for food preparation. Most of the households do not have access to electricity throughout the month.

- Water is not available in all the households. In most cases, water has to be fetched from outside the home.

- Sanitation and hygiene conditions are not ideal.

- Education and literacy levels are generally low.

- Most of the population belong to the Tswana group, therefore traditional Tswana eating habits must be considered.

- There is little evidence of feeding schemes in the community.

- The community has limited access to vegetable gardens.

- The absence of comprehensive health care services indicates that no nutritionists are working in the community. This observation emphasises the need for sound nutrition education. 
TABLE 3:

DATA COLLECTED DURING THE COMMUNITY PROFILE STUDY IN TSHING (N = 149)

\begin{tabular}{|c|c|c|}
\hline Variable & $\mathbf{N}$ & $\%$ \\
\hline Vegetable gardens & 29 & 19,5 \\
\hline \multicolumn{3}{|l|}{ Water* } \\
\hline Borehole & 1 & 0,7 \\
\hline Tap water outside home on own stand & 46 & 30,9 \\
\hline Tap water outside shared & 102 & 68,9 \\
\hline Tap in house & 4 & 2,7 \\
\hline Rainwater tank & 2 & 1,3 \\
\hline \multicolumn{3}{|l|}{ Housing } \\
\hline Brick house & 43 & 28,7 \\
\hline Structured zinc & 104 & 70,0 \\
\hline Traditional hut & 2 & 1,3 \\
\hline \multicolumn{3}{|l|}{ Energy source for cooking ${ }^{*}$} \\
\hline Electricity (card system) & 12 & 8 \\
\hline Gas & 19 & 12,8 \\
\hline Primus stove (paraffin) & 103 & 69,0 \\
\hline Wood fire & 16 & 10,7 \\
\hline Coal stove & 58 & 38,9 \\
\hline \multicolumn{3}{|l|}{ Refuse facilities* } \\
\hline Drum and refuse bags on stand & 146 & 97,9 \\
\hline Shared drum and refuse bags & 3 & 2,0 \\
\hline Common refuse dump & 10 & 6,7 \\
\hline Dump in open area & 1 & 0,7 \\
\hline \multicolumn{3}{|l|}{ Refuse removal } \\
\hline Twice a week & 14 & 9,5 \\
\hline Once a week & 68 & 45,6 \\
\hline Every two weeks & 44 & 29,5 \\
\hline Once a month & 20 & 13,4 \\
\hline Never & 3 & 2,0 \\
\hline \multicolumn{3}{|l|}{ Toilet facilities } \\
\hline Own flush toilet inside & 6 & 4,0 \\
\hline Own flush toilet outside & 3 & 2,0 \\
\hline Own pit toilet outside & 138 & 92,6 \\
\hline Share a pit toilet & 2 & 1,4 \\
\hline \multicolumn{3}{|c|}{$\begin{array}{l}\text { Community organisations and health services in the com- } \\
\text { munity }\end{array}$} \\
\hline Youth club & 1 & \\
\hline Church organisations & 20 & \\
\hline RDP office & 1 & \\
\hline Soccer clubs & 2 & \\
\hline Clinics & 2 & \\
\hline Provincial hospital & 1 & \\
\hline
\end{tabular}

* More than one option could be selected 
- A nutrition education programme should be implemented via the existing community structures (Report of the Nutrition Committee, 1994:62). In Tshing there is evidence of fairly strong church organisations who could probably be used for implementation of the nutrition programme.

- Poverty in the township is extensive.

\section{Step 5}

The fifth step in the research process used focus groups to obtain additional information on eating patterns and health. The procedures that were followed included question development, group recruitment, focus-group interview logistics and data analysis (Krueger, 1988:1). Questions were compiled according to the aim of the research. Language proficiency, education and literacy skills were considered. The questions and prompts were clustered according to the focus-group discussion phases identified by Krueger (1988), namely opening question, introductory question, transition question, key questions and ending question.

The samples for the focus groups consisted of six groups of approximately eight women each to represent the populations that were studied. These groups were identified and recruited by the local clinic sisters. They chose the homes of women ranging from the higher-income group, residing in brick houses with water and electricity, to the lowest-income group, residing in tin shanties in the informal settlements with no services whatsoever. The focus groups were composed of people who were similar to each other in terms of age and socioeconomic status. The women were all wives and mothers and were responsible for the wellbeing of their families.

The members of the research team consisted of a facilitator who directed the conversation according to the structured questions, and a recorder who took written notes and audiotaped the discussions. These discussions were held in a living room of one of the participants to ensure a neutral environment where refreshments were served at the beginning of each session. All the women could understand and speak elementary Afrikaans and some could speak English. Where Tswana or Xhosa terms were given for foods, the women could give clear descriptions of the foods in Afrikaans. There was no need for translators.

The written notes and tape recordings were compared after each session and the notes were analysed for emerging trends and patterns in the responses. Two members of the research team independently identified major response patterns in the different sessions in order to increase the reliability of the results (Krueger, 1988). The following were general conclusions from the focus-group discussions:

- Knowledge about nutrition and health issues varies according to the different socioeconomic strata of the community. Misconceptions exist, especially in the lower-income groups.
- Eating patterns are linked to the socioeconomic strata. The higher the income group, the more Westernised the eating pattern. The lower-income groups are more inclined to traditional African eating patterns based on maize meal as the staple food, with added variety which is determined by their income.

- Food is available to the community via shops in the town area which is within walking distance, about two to four kilometres from the township. Maize meal is bought in bulk (12,5 kg packs) from a shop in town at the end of the month, where it is available at a special price. However, this particular brand is not enriched with vitamins. Informal and relatively expensive shops are available in the community. These informal shops supply very basic foods like maize meal, sugar, coffee, vegetable oil and tinned fish. The data on food prices and availability obtained during the focus-group discussions were confirmed when these shops were visited (sixth step).

- Although some of the women are aware of the importance of healthy eating patterns, they are severely constrained by insufficient financial means.

- Producing food by cultivating vegetable gardens and raising chicken is not a priority in the community.

- The women are aware that eating habits are related to health. This awareness is, however, based on many misconceptions, for example that nondairy creamer is a kind of milk, and "old wives" tales, for example that beetroot helps to make "strong blood".

- The women find that fuel sources for the cooking and preservation of food are scarce and expensive.

In summary, therefore, it may be stated that issues surrounding nutrition and health are problematic because of both poverty and a lack of knowledge. Any NIEP would have to address the misconceptions that were identified as well as economical ways to make the best use of the available money and other resources.

\section{Step 6}

The availability of food items in informal shops in the target population was monitored during the sixth step of the research process. These informal or spaza shops (a living area, garage or room converted into a shop) are viewed as one of the food gatekeepers in the food chain. Moreover, eating habits are affected by the availability of food. Fourteen shops in the target communities were surveyed by final-year Dietetics students who made use of food information tables compiled by the Department of Health in Pretoria.

The following deductions were made from the data:

- Full-cream milk and nondairy creamers are freely available, but the alternative for creamers, namely skimmed low-fat powdered milk, is not kept in any 
of the shops.

- Stewing beef and a variety of chicken products (whole chicken, portions, chicken feet, neck, liver and gizzards) are available, whereas minced meat, offal (sheep's intestines, lungs, feet, also called tripe) and mutton are not available at all.

- Tinned meat, eggs and baked beans are popular commodities.

- A very limited variety of fresh vegetables is available. Popular vegetables are tomatoes and onions, probably because most people make a tomato and onion sauce almost daily. Tinned peas, mixed vegetables and beetroot are freely available.

- Seasonal fresh fruit is available in the shops. At the time of the study (winter) oranges, apples and bananas were available. Tinned peaches and pears are available at a few shops.

- There is a great demand for sunflower seed oil which is evidently used in the cooking of most foods. Soft margarine is evidently not sold, probably due to the lack of cooling facilities and the fact that most houses do not have electricity or gas for refrigerators (Table 3). Hard margarine is preferred because it does not have to be stored in a refrigerator.

- Brown and white bread are available in all the shops, but the more nutritious wholewheat bread is not available at all. Cereals with a higher nutrient density such as oats and Maltabella are also scarce compared to the readily available maize meal. The price of maize meal is, however, much lower than that of oats and Maltabella. Cake flour and white bread flour are also readily available compared to brown bread meal and nutty wheat flour. White rice is freely available. Uncooked pasta is scarce whereas tinned spaghetti in tomato sauce is sold at all the shops.

- Tomato sauce, jam and golden syrup are readily available and are apparently considered luxury items. Carbonated cold drinks and cordials are freely available whereas fruit juices are available in a limited number of shops as they are more expensive than carbonated cold drinks and cordials.

It is obvious that the shopkeepers influence the eating patterns via their supply of certain items. From a nutrition perspective the following should be emphasised:

- The use of skimmed milk products instead of nondairy creamers should be promoted as a product with a long shelf-life which can be used in tea and coffee. Those who use fresh milk should be encouraged to continue using it.

- Using a variety of fresh fruit and vegetables should be promoted.

- The risk of degenerative diseases increases with obesity, which is associated with high fat intakes (Lissner \& Heitman, 1995:79). The excessive use of all kinds of fats and oils in food preparation should be addressed, since a high incidence of obesity was found during the first part of the THUSA I study (Vorster, 1997).

- The health advantages of using whole-grain cere- als should be promoted.

- The availability of enriched maize meal should be investigated and the health advantages of enriched maize meal should be explained, since riboflavin and niacin intakes could be increased by using enriched maize meal. In the THUSA I study low intakes of several micronutrients, including riboflavin and niacin, were found (Maclntyre, 1998).

\section{Step 7}

In the seventh step the food security status of the target population was investigated by using a standardised hunger and food security assessment scale (Hanekom et al, 1997). This scale is based on the Radimer/Cornell Measure of Hunger and Food Security Scale (Kendall et al, 1995:2793). It consists of 15 statements and 5 response categories (never, sometimes, half the time, often and always). In a pilot study the construct validity $(0,81)$, content validity $(0,81)$ and reliability coefficient $(0,97)$ of the scale indicated that this questionnaire is a valid and reliable measuring instrument for food security (Hanekom et al, 1997).

The same sample of subjects were interviewed as in the profile study, producing 149 completed questionnaires. Six final-year Dietetics students were fully trained to assist with data collection. According to the definition of food security, all people must have access to enough food at all times for an active, healthy life. This includes, at a minimum, the ready availability of nutritionally adequate and safe foods and the assured ability to acquire acceptable foods in socially acceptable ways (Kendal et al, 1995:2794).

A clinical cutting score was calculated in order to classify the respondents in the categories of food secure, low grade of food insecurity, and severe hunger. The distribution on the hunger and food security assessment scale showed that $9 \%$ of the community could be described as experiencing food security, 38\% experienced a low grade of food insecurity, and $53 \%$ of the respondents experienced severe hunger. A low grade of food insecurity is reflected in frequent "sometimes" responses, for example "My food runs out before I get money to buy more", "I don't know where the next day's food is going to come from" and "I don't have enough money for food". Severe hunger was defined as a score above the clinical cutting score range (clinical cutting score \pm standard error of measurement), and reflected frequent responses like these: "Half the time", "often" or "always" on the questionnaire statements representing hunger. The complex association between food insecurity and obesity falls outside the scope of this study.

\section{Step 8}

The eighth step of the research process recorded dietary intakes by using a standardised quantitative food frequency questionnaire (QFFQ) and a food portion picture book to assess portion sizes. The questionnaire was specifically developed to assess the dietary 
intake of blacks in the North-West Province and it was found to be valid and reliable (Maclntyre, 1998) although QFFQs often overestimate dietary intake (Faber et al, 1990:10).

Five trained field workers interviewed the person who was responsible for food preparation in the 149 randomly selected households, since this person could probably provide sufficiently reliable information about methods of food preparation and frequency of intakes, which were used to estimate the intake per household. The mean dietary intakes of the subjects are presented in Tables 4 (energy and macronutrients) and 5 (micronutrients).

The diets of most subjects lacked variety, consisting mainly of maize meal porridge. Their energy intakes were adequate and obesity was evident in some cases. Micronutrient intakes, specifically of ascorbic acid, vitamin $B_{6}$ and folate as well as fibre were not adequate. Some of the subjects made prudent food choices in terms of the available money, using lowcost plant protein. Enriched maize meal was seldom used ( $9 \%$ of the subjects). Nondairy creamers were commonly used instead of milk.

\section{Step 9}

The Schutte Scale ( $P$ Index) was used in two focus groups during the ninth step of the research process to determine the community's perceptions of priority of a nutrition-related topic. This technique brings the perception of the importance of a previously identified topic into context with their satisfaction (Schutte, 1992). The most important topic the participants identified was nutritious food, followed by snacks between meals, economical cooking methods, portable meals, budgeting, healthy cooking methods and vegetable gardens. The focus groups answered the question whether the community would benefit from a NIEP with an overwhelming "yes".

\section{Step 10}

The actual design of the NIEP for the target community formed the tenth step in the research. After a comprehensive study of the research findings that were required for the first nine steps, the researchers were able to design a NIEP through a process of analysis, interpretation and synthesis of the collected data. Since the intervention was planned for Tshing, only data of the intervention group were taken into account. The data may be summarised as follows:

Staple food The staple food of the target community is maize meal which is prepared in a variety of ways and served with a variety of foods (fifth and eighth steps). Maize is often the only food of the extremely poor people in the community. Enriched maize meal is freely available, but is more expensive than unenriched maize meal (sixth step). The researchers realised that it would be difficult to persuade the community to buy a more expensive product when it is not evident that the enriched maize has a higher nutrient content. Eating enriched maize meal would address the identified shortage of riboflavin and niacin in the diet (eighth step). Brown bread is cheaper than white bread and it contains more micronutrients and fibre. Eating brown bread instead of white bread would be an economical way of including more micronutrients and fibre in the diet.

Protein food Dry beans are an inexpensive protein source and would supplement the proteins found in maize meal as well as various micronutrients such as vitamin B6, folic acid, calcium, iron and fibre. The diets of the subjects were found to be low in these nutrients (Table 5). Dry beans, however, take a long time and much energy to cook. An economical way of cooking beans should be included in the NIEP, since the focus groups (ninth step) stated that this was important. The hay box can be used to cook maize meal porridge and dry beans, but not fish, chicken or meat products.

Offal, eggs and tinned fish are inexpensive and highly nutritious protein foods. According to the dietary intake data, information from the focus-groups discussions and shop inventories, these foods are popular and should therefore be promoted in the NIEP. Processed meats such as polony, vienna sausages and cold meat loaves have a high fat content and represent poor value for money.

Cooling facilities for fresh milk are limited since the demographic data showed that few households had electricity or gas for fridges. Powdered milk has a longer shelf life, it is more economical and is easy to use. Skimmed powdered milk is a good source of protein, calcium and riboflavin, of which relatively low intakes were found (Tables 4 and 5). Nondairy creamers contain high levels of fat and lack essential nutrients. The focus-group results and dietary data showed that many people use creamers and believed it to be similar to milk.

Fruit and vegetables Fresh fruit and vegetables are rich in micronutrients, particular vitamins $\mathrm{A}$ and $\mathrm{C}$. The use of relatively inexpensive vegetables such as spinach, beetroot (both the leaves and root), cabbage, pumpkin, sweet potatoes, potatoes, tomatoes and onions should be promoted since low intakes of these micronutrients were found. Fruit and raw vegetables such as cabbage leaves or carrots as a snack or food for lunch boxes should be promoted. Seasonal fruit are less expensive. The cultivation of vegetable gardens and planting fruit trees should be promoted, since only $19,5 \%$ of the households had vegetable gardens (Table 3 ).

Snacking The dietary data (eighth step) showed that carbonated cold drinks, cordials, potato crisps, sweets, chocolates and puffed fried maize products were eaten often, despite the fact that the participants in the focus-group discussions (sixth step) stated that they did not have enough money to buy food. These snack foods were generally available in the spaza shops (seventh step). Fresh fruit juices and milk in- 
TABLE 4

ENERGY AND MACRONUTRIENT INTAKE OF SUBJECTS COMPARED TO STANDARDS ( $N$ = 149 FEMALE SUBJECTS IN TSHING)

\begin{tabular}{|c|c|c|c|c|c|}
\hline \multirow[t]{2}{*}{ Nutrient } & \multirow{2}{*}{$\begin{array}{c}\text { RDA women } \\
25-50 \\
\text { Dietary goal }\end{array}$} & \multirow[t]{2}{*}{$\begin{array}{l}\text { WHO recom- } \\
\text { mendation }\end{array}$} & \multirow[t]{2}{*}{$\begin{array}{c}\text { Mean } \pm \text { SD*THUSA } \\
\text { II sample }\end{array}$} & \multicolumn{2}{|c|}{$\begin{array}{c}\text { Mean } \pm \text { SD SANSS\# methods } \\
\text { other than } 24 \text {-hour recall }\end{array}$} \\
\hline & & & & Urban black & Rural black \\
\hline Energy (kJ) & 9240 & $\begin{array}{l}\text { Varies with body } \\
\text { size and activity }\end{array}$ & $7892 \pm 3662$ & $9523 \pm 3737$ & $8968 \pm 3267$ \\
\hline Carbohydrates (g) & - & - & $295 \pm 129$ & $298 \pm 150$ & $297 \pm 89$ \\
\hline Protein (g) & 50 & 50 & $51,2 \pm 26,3$ & $71,2 \pm 33,3$ & $70,3 \pm 26,9$ \\
\hline Animal protein (g) & & & $20,2 \pm 16,2$ & & \\
\hline Plant protein $(\mathrm{g})$ & & & $30,7 \pm 14,4$ & & \\
\hline Total fat (g) & - & - & $51,4 \pm 32,6$ & $85,4 \pm 62,5$ & $60,7 \pm 31,2$ \\
\hline $\begin{array}{l}\text { Percentage total en- } \\
\text { ergy provided by fat }\end{array}$ & $<30$ & & $23,0 \pm 8,0$ & 40,1 & 25,7 \\
\hline Dietary fibre (g) & $25-30$ & - & $16,0 \pm 8,2$ & $18,6 \pm 9,4$ & $25,1 \pm 9,18$ \\
\hline Sugar (g) & - & - & $59,7 \pm 53,7$ & $94,2 \pm 67,6$ & $44,6 \pm 36,4$ \\
\hline
\end{tabular}

* $\mathrm{SD}=$ standard deviation

\# SANSS = South African Nutrition Survey Study Group (Vorster et al, 1997)

TABLE 5 MICRONUTRIENT INTAKE OF SAMPLE COMPARED TO STANDARDS (N = 149 FEMALE SUBJECTS IN TSHING)

\begin{tabular}{|c|c|c|c|c|c|}
\hline Nutrient & $\begin{array}{l}\text { RDA women } \\
25-50 \text { years } \\
\text { dietary goal }\end{array}$ & $\begin{array}{l}\text { WHO recom- } \\
\text { mendation }\end{array}$ & $\begin{array}{c}\text { Mean } \pm \text { SD* } \\
\text { THUSA II sample }\end{array}$ & $\begin{array}{l}\text { Percentage of sub- } \\
\text { jects with intake } \\
<67 \% \text { RDA }\end{array}$ & \begin{tabular}{|c|} 
Percentage of sub- \\
jects with intake \\
$<67 \%$ WHO recom- \\
mendation \\
\end{tabular} \\
\hline Calcium (mg) & 800 & 400 & $364,0 \pm 290,9$ & 69,1 & 51.0 \\
\hline Iron (mg) & 15 & 14 & $9,29 \pm 4,86$ & 59,7 & 59.1 \\
\hline Magnesium (mg) & 280 & - & $256,3 \pm 133,3$ & 38,9 & - \\
\hline Zinc (mg) & 12 & - & $6,63 \pm 3,75$ & 62,4 & - \\
\hline Vitamin A (RE) & 800 & 750 & $590,4 \pm 505,5$ & 55,7 & 52.3 \\
\hline Thiamine (mg) & 1,1 & 0,9 & $1,01 \pm 0,51$ & 37,6 & 24.8 \\
\hline Riboflavine (mg) & 1,3 & 1,3 & $0,94 \pm 0,6$ & 25,5 & 25.5 \\
\hline Niacin (mg) & 15 & 14,5 & $10,3 \pm 6,2$ & 52,3 & 51.7 \\
\hline Vitamin $\mathrm{B}_{6}(\mathrm{mg})$ & 1,6 & - & $0,7 \pm 0,5$ & 67,1 & - \\
\hline Folic acid $(\mu \mathrm{g})$ & 180 & 200 & $110,4 \pm 80,4$ & 57,0 & 69.1 \\
\hline Vitamin $B_{12}(\mu \mathrm{g})$ & 2 & 2 & $2,5 \pm 2,2$ & 36,9 & 36.9 \\
\hline Ascorbic acid (mg) & 60 & 30 & $28,2 \pm 27,6$ & 77,9 & 69.1 \\
\hline Vitamin E (mg) & 8 & - & $12,11 \pm 8,4$ & 14,8 & - \\
\hline
\end{tabular}

* $\mathrm{SD}=$ standard deviation

stead of carbonated cold drinks and artificially sweetened cordials, and popcorn and peanuts instead of sweets should be recommended as snacks. Betweenmeal snacks and portable meals were among the most important nutrition-related topics identified by the focus-group participants (ninth step).
Energy sources for cooking An economical way of cooking should be included in the NIEP. The focus groups indicated this as being important.

Consultation with community leaders, including senior school teachers, group leaders of church organisations, spaza shop owners and women involved in a 
feeding scheme for Tshing, facilitated the design of the intervention programme. Numerous brainstorming sessions and consultative meetings were held by the researchers themselves and controversial issues concerning the programme design were debated at length. The research team again consulted the literature on nutrition status and nutrition education as well as experts in the field of health education (The Soul City Team, Johannesburg) to resolve controversies. Eventually the following nutrition messages were formulated, based on the available data:

- Promoting the use of enriched maize meal to increase the micronutrient intake (riboflavin and niacin) since low intakes of these nutrients were identified during the eighth step

- Promoting the consumption of cooked dry beans to contribute inexpensive protein, fibre and micronutrients (iron and folate) without increasing the total fat intake (Due to the generally low household incomes (identified during the fourth step), it would be important to include low-cost food with a high protein and micronutrient content and restrict fat intake, since obesity in women was common in the THUSA I study (step two).)

- Promoting the use of skimmed dried milk powder instead of nondairy creamers to increase protein, calcium and riboflavin intakes (low intakes were identified during the eighth step) without increasing the fat intake

- Promoting the consumption of fresh fruit and vegetables to contribute ascorbic acid, vitamin $A$, folate and fibre (low intakes were identified during the eighth step) without increasing the fat intake

- Ensuring good "value for money" meat to ensure an adequate protein intake despite the limited household income (Table 2)

- Promoting healthy snacking to contribute micronutrients without increasing the fat intake and to ensure buying value-for-money snacks rather than foods that supply energy only

- Promoting the use of brown bread to increase fibre, iron and B-vitamin intake from a less expensive food than white bread (The use of wholewheat bread would also be promoted, but wholewheat bread was not generally available in the shops in the target community.)

- Promoting economical cooking methods since energy resources are expensive (fourth and fifth steps).

Messages 1, 2, 3, 4, 5 and 6 are intended to address micronutrient undernutrition, and messages 2, 3, 4, 5 and 6 address overnutrition, specifically of fat intake, which is associated with obesity. Messages 2, 5, 6, 7 and 8 address the problem of poverty.

After the selection and finalisation of eight major nutrition messages to form the core of the programme, the researchers decided on a title for the NIEP to attract attention to the programme. It was decided to call the programme The Great 8 Nutrition Programme: Better eating for better health. The main aim of the Great 8 Nutrition Programme is contained in the logo Better eating for better health. The aim is to improve health and quality of life through sound nutrition. The specific objectives are directly related to the eight nutrition messages which form the contents of the programme.

\section{PLAN OF ACTION}

These messages are contained in a full-colour booklet with culturally friendly illustrations for illiterate women and notes in English, Afrikaans and Tswana. Coloured pamphlets and posters were designed to depict the eight messages with illustrations. A full discussion of the implementation and evaluation of the Great 8 Nutrition Programme is beyond the scope of this article. All aspects of implementation are to be monitored and evaluated by means of pretesting and posttesting, incorporating a multimethodological approach. Focus groups would be used in both pretesting and posttesting to assess eating patterns and information about health. Inventory lists of the spaza shops in the community, drawn up before and after the intervention, would be compared to assess whether the shopkeepers had to stock more of the foods that were promoted in the NIEP. Ownership of the programme would be transferred to the community during implementation.

\section{CONCLUSIONS}

The following general conclusions arise from this research:

- NIEPs are needed, particularly by the developing communities in South Africa.

- Detailed situation analyses should be carried out in specific communities and intervention programmes should target the specific needs of the group.

- The nutrition education messages in any intervention programme should be clear and easy to understand.

- The programme should be designed to target all stakeholders in the community.

- The programme should be designed to ensure full participation of the target group and ownership should be transferred to the community.

- The programme should ensure capacity building in the community.

- The most needy people in the community should be the main target of an intervention programme.

The Great 8 Nutrition Programme is expected to make a significant difference in the eating patterns of the Tshing community. It could also form the basis of NIEPs for many similar communities in the NorthWest Province to contribute to better health and an improved quality of life.

Acknowledgements: The authors would like to thank Sally Ward of Soul City, Johannesburg, for her advice and the final-year Dietetics students of 1997 
for their assistance during the development of this NIEP.

\section{REFERENCES}

ACHTERBERG, C (1992): Effective communication for behavior change. Nutr Today 27:29-30.

AMERICAN DIETETIC ASSOCIATION (1990): Position of the American Dietetic Association: nutrition education for the public. J Am Diet Assoc 90(1):107-110.

CLIFF, EC \& FREIMUTH, V (1995). Health communication: what is it and what can it do for you? J Health Educ 26 (2):68-74.

DONOVAN, FJ (1995). Steps in planning and developing health communication campaigns: a comment on CDC's framework for health communication. Public Health Rep 110 (2):215-217.

FABER, M, GOUWS, E, VAN STADEN, E, WOLMARANS, P \& BENADE, AJS (1990): Comparison of the 24-hour dietary recall and the 7-day estimated dietary record methods for determining the mean nutrient intake of a population. S Afr J Food Sci Nutr 2:10-17.

HANEKOM, AJ, HANEKOM, SM \& FAUL, AS (1997): Hunger and food security assessment scale. Pretoria. Perspective Training College. Unpublished.

KENDALL, A, OLSON, CM \& FRONGILLO, EA (1995): Validation of the Radimer/Cornell measures of hunger and food insecurity. J Nutr 125:2793-2801.

KOK, G (1992): Quality of planning as a decisive determinant of health education effectiveness. Hygiene 11(4):5-9.

KRUEGER, RA (1988): Focus groups: a practical guide for applied research. Newbury Park, Cal. Sage.

KUMANYIKA, S (1996): Improving our diet - still a long way to go. New Engl J Med 335(10):738-740.

LADZANI, R, STEYN, NP \& NEL, JH (1992): A socioeconomic profile of households in semi-rural areas of Lebowa with specific reference to dietary habits. S Afr J Food Sci Nutr 4(3):60-63.

LERER, L \& YACH, D (1998): Infrastructural development, the RDP and health. Urban Health News 24:3-5.

LILLEY, JM \& JOHNSON, EA (1994): Health and diet in a rural area: the construction of food choice in later life. Nutr Food Sci 5:22-25.

LISSNER, L \& HEITMANN, BL (1995): Dietary fat and obesity: evidence from epidemiology. Eur J Clin Nutr 49:79-90. MACINTYRE, UE (1998): Dietary intakes of Africans in transition in the North-West Province. PhD thesis. Potchefstroom. Potchefstroom University for CHE MCLACHLAN, M (1994): Learning about nutrition program- ming: the NNSDP experience. S Afr J Food Sci Nutr 6(1):12.

MCLACHLAN, M \& MARSHALL, C (1995): Nutrition in South Africa: a proposal for transformation. Unpublished draft for the World Bank and Development Bank of South Africa.

MCLACHLAN, M \& VAN TWISK, P (1995): The RDP and nutrition: what role for the food industry? S Afr J Food Sci Nutr 7(1):1-3.

PATEL, DN \& PETTIFOR, JM (1992): Editorial comment: malnutrition in South Africa. S Afr J Food Sci Nutr 4(2):2224.

PINCUS, T \& CALLAHAN, LF (1994): Associations of low formal education level and poor health status: behavioural, in addition to demographic, and medical explanations? J Clin Epidemiol 47(4):355-361.

POLICY STATEMENT ON NUTRITION EDUCATION FOR THE PUBLIC (1995): J Am Diet Assoc 85(8):980-981.

POPKIN, BM \& DOAK, CM (1998): The obesity epidemic is a world-wide phenomenon. Nutr Rev 56(4):106-114.

REPORT OF THE NUTRITION COMMITTEE TO THE MINISTER OF HEALTH (1994): An integrated nutrition strategy for South Africa. Pretoria.

RIMM, AA, HARTZ, AJ, KALBFLEISCH, JH, ANDERSON, AJ \& HOFFMANN, RG (1980): Basic biostatistics in medicine and epidemiology. New York, Appleton-Century-Crofts. SCHUTTE, DW (1992): Prioritisering van gemeenskapsbehoeftes Kaapstad. RGN. Ongepubliseer.

STECKLER, A, ALLEGRANTE, JP, ALTMAN, D, BROWN, R, BURDINE, JN, GOODMAN, RM \& JORGENSEN, C (1995): Health education, intervention strategies: recommendations for future research. Health Educ Q 22(3):307325.

STECKLER, A, ORVILLE, K, ENG, E \& DAWSON, L (1992): Summary of a formative evaluation of PATCH. J Health Educ 23:174-178.

STEYN, M (1990): Formative evaluation of health education. Nurs RSA 5(5):36-40.

STEYN, NP, PETTIFOR, JM, VAN NIEKERK, L \& NEL, JH (1992): Supplementary school feeding and nutritional status of primary school children in the Richtersveld. S Afr J Food Sci Nutr 4(4):103-109.

VORSTER, HH (1997): Framework for a protocol of a transition project. Potchefstroom. Potchefstroom University for CHE. Unpublished.

VORSTER, HH, OOSTHUIZEN, W, JERLING, JC, VELDMAN, FJ \& BURGER, HM (1997): The nutritional status of South Africans. A review of the literature from 1975 to 1996. Part 1. Durban. Health Systems Trust.

WALKER, ARP (1989): Reflections on Mamre - what is happening elsewhere? S Afr Med J 75:43-45. 